DOI: 10.33310/2518-7813-2019-65-2-319-322

УДК [37.016:008:7]:37.091.33

\title{
Юлія ХАЙРУЛЛІНА
}

кандидат філософських наук, доцент

старший викладач кафедри музичного мистецтва

Миколаївського національного університету імені В. О. Сухомлинського,

м. Миколаїв, Украӥна

e-mail: polnujstil@gmail.com

\section{ЗАСОБИ ХУДОЖНЬОЇ ДРАМАТУРГІЇ У ПІДГОТОВЦІ ВЧИТЕЛЯ МУЗИЧНОГО МИСТЕЦТВА ДО ВИКЛАДАННЯ ІНТЕГРОВАНОГО КУРСУ «МИСТЕЦТВО» В УМОВАХ НОВОЇ УКРАЇНСЬКОЇ ШКОЛИ}

\begin{abstract}
В статті проаналізовано методичні засади підготовки майбутнього вчителя музичного мистецтва до викладання інтегрованого курсу «Мистецтво» в умовах нової української школи. Актуалізовано явище художньої драматургії в контексті застосування їі закономірностей у педагогіці мистецтва. Розглянуто особливості використання прийомів художньої драматургії при впорядкуванні структурнозмістових елементів сучасного уроку мистецтва у закладі загальної середньої освіти. Надано рекомендації щодо застосування художньої драматургії як освітньої технології. Описано рівні використання художньої драматургії на уроці. Наведено схему уроку мистецтва, де поєднуються загальнодидактичні вимоги та елементи художньої драматургії. Рекомендовано методику відстеження емоційної реакції учнів на хід уроку мистецтва з метою прогнозування успішної навчальної діяльності та вдосконалення методичної підготовки майбутніх вчителів мистецтва.

Ключові слова: Нова украӥнська школа, вчитель музичного мистецтва, художня драматургія, інтегрований курс «Мистецтво», урок мистецтва, освітня технологія, емоційна партитура уроку.
\end{abstract}

Становлення нової Української школи докорінно впливає на розвиток усіх ланок освіти. Одним з напрямків, який зазнає революційних змін $€$ сфера художньо-естетичної освіти, галузь «Мистецтво». У зв'язку з цим науково-методичний дискурс мистецької освіти є дуже активним: аналізуються та обговорюються програмне забезпечення, свобода тематичної комбінаторики, очікувані результати - система компонентів компетентностей, тощо. Однією з тем яка потребує додаткового вивчення $є$ проблема відповідності дидактичних засобів оновленому змісту мистецької освіти. Методичний інструментарій уроку мистецтва містить як загальнодидактичні, так і специфічні засоби, серед яких найбільш характерним є метод художньо-педагогічної драматургії .

Драматургія, як «мистецтво побудови драматичного твору» описана ще Аристотелем, тоді-ж сформульовано головну ознаку як наявність дії,змін подій в часі. Використання драматургії у педагогіці починається ще у 60-ті 70-ті роки XX століття, коли втілення нових програм для загальноосвітньої школи потребували оновлених методичних підходів. Експериментальні програми 3 музики Д. Кабалевського (де драматургія виступає універсальним засобом організації процесів естетичного сприйняття творів музичного мистецтва на уроці в школі) та «Світової художньої культури» Л. Предтеченської (де художня драматургія поступово перетворюється у метод організації освітнього простору уроку) це етапи розвитку інтегрованої художньо-естетичної освіти та, водночас площадки апробації новітніх методичних засобів. Українські дослідники галузі мистецької педагогіки теж приділяли і приділяють увагу драматургії в контексті визначення їі роли у опануванні мистецтва в школі . В різні часи проблема художньої драматургії знайшла відображення у працях О. Рудницької [5, 170], О. Щолокової [6], Г. Падалки [4, 193-196], Л. Масол [2, 60-62]. Артикуляція методу художньо-педагогічної драматургії достатньо різноманітна: «вибір послідовності та форм діяльності на уроці» (Д. Кабалевский), «моделювання художньо-творчого процесу» (Л. Школяр), «розвиток співчуття до прикладів мистецтва, у перенесенні почуттів та думок з художніх творів до подій реального життя» (Л. Масол) тощо. В багатьох визначеннях даного поняття фігурують процеси організації дії (сприйняття, пізнання, співчуття) отже, перейдемо до розгляду проблеми практичної реалізації методу художньо-педагогічної драматургії на уроці в закладі загальної середньої освіти. Виходячи 3 цього метою даної статті стала актуалізація методичного інструментарію уроку мистецтва на прикладі методу художньо-педагогічної драматургії.

Застосування методу художньо-педагогічної драматургії охоплює всі складові процесу мистецької освіти: від реципієнтів художньо-педагогичної інформації - учнів, змісту освіти - мистецтва, 
Таблиця 1 - Формування структури уроку мистецтва

\begin{tabular}{|c|c|c|}
\hline $\begin{array}{c}\text { Загальнодидактична } \\
\text { схема уроку мистецтва }\end{array}$ & $\begin{array}{c}\text { Етапи художньої } \\
\text { драматургії уроку } \\
\text { мистецтва }\end{array}$ & $\begin{array}{c}\text { Педагогічний зміст } \\
\text { етапів уроку мистецтва }\end{array}$ \\
\hline Організаційний момент & пролог & $\begin{array}{l}\text { Адаптація сприйняття художньо- педагогічного } \\
\text { матеріалу уроку }\end{array}$ \\
\hline Мотивація навчальної діяльності & зав'язка & Створення проблемної ситуації \\
\hline Актуалізація опорних знань & екпозиція & Активізація попереднього художнього досвіду \\
\hline Викладення нового матеріалу & кульмінація & $\begin{array}{l}\text { Організація процесу художньо-естетичного сприй- } \\
\text { няття }\end{array}$ \\
\hline Актуалізація набутих знань & розвиток дії & Організація художньо-естетичної діяльності \\
\hline Рефлексія навчальної діяльності & епілог & $\begin{array}{l}\text { Формування цілісного образу уроку, вирішення } \\
\text { моральної проблеми заняття }\end{array}$ \\
\hline
\end{tabular}

методичного інструментарію, до транслятора художньо-педагогічної інформації - самого вчителя. Виходячи $з$ положення про те, що мистецтву треба навчати засобами мистецтва, доцільно ставитися до кожного уроку як до «педагогічного твору», подібного до музичного, літературного, або драматичного, адже урок теж має початок, кінець, виконавця, глядача та сюжет, заснований на дії. Будова «традиційного уроку», що була здатна «увібрати в себе» зміст усіх шкільних дисциплін виявилася затісною для уроку мистецтва, тому логічним стало поєднання двох схем: загальнодидактичної структури уроку та драматургічної послідовності (пролог, зав'язка, розвиток, кульмінація, розв'язка, епілог). Також, виходячи з законів драматургії та екстраполюючи їх на дидактичну схему шкільного заняття обов'язковою умовою при розробці сценарію уроку мистецтва стає передбачення суттєвого контрасту складових елементів, що повинно сприяти створенню дії та емоційної кульмінації. У наступній таблиці синхронізуються загальнодидакична структура та етапи художньої драматургії їз визначенням педагогічного змісту кожного з елементів уроку.

Доцільно виявити функції вчителя, як своєрідного транслятора художньо-педагогічної інформації на уроці художньої культури. Слід підкреслити, що викладати подібний предмет має особлива людина, яка здатна осягнути, поєднати та адекватно інтерпретувати інформацію 3 різних джерел: як мистецьких (література, музика, хореографія, образотворче та драматичне мистецтво), так і загальногуманітарних (історія, філософія, релігієзнавство). Квінтесенцією цього поєднання стає дійство уроку, яке вчитель повинен провести зі справжньою акторською майстерністю. Конспект подібного уроку перетворюється у художньо-педагогічній сценарій, де позначаються умовні емоційні акценти, відповідно до особливостей сприйняття дитини, найбільш влучні моменти для створення емоційно смислової кульмінації, зауважено про моменти, коли увага дітей може знизитись і це буде сигналом для зміни форми роботи, оскільки знання 3 уроку мистецтва дитина отримує через «браму почуттів», вже потім емоційне враження пройде шлях до раціонального осмислення, та засвоєння.

Передбачення емоційної реакції аудиторії $\epsilon$ однією з складових педагогічної майстерності вчителя, його вміння прогнозувати ефект від художньо-педагогічного впливу. Пропонуємо унаочнити очікувану реакцію учнів за допомогою схеми «емоційної партитури», яка допоможе молодому вчителеві співвіднести бажаний результат із реально отриманим на уроці. (Робота 3 даною таблицею пройшла випробування при проведенні багаторічних педагогічних практик з художньої культури (з 2003 - по 2018 рр.) у школах та гімназіях міста Миколаєва та дозволила практикантамспостерігачам оцінити ефективність роботи колег - практикантів-вчителів).

\section{Таблиця 2 - Емоційна партитура уроку мистецтва}

Емоційні реакції учнів на уроці

\begin{tabular}{|c|c|c|c|c|c|c|c|c|c|}
\hline \multirow{3}{*}{$\begin{array}{l}\text { Позитивні } \\
\text { реакції }\end{array}$} & $\begin{array}{l}\text { Бурна реакція, адекватна змісту } \\
\text { художнього матеріалу (сміх, сльози) }\end{array}$ & & & & & & & & \\
\hline & Глибока тиша, увага & & & & & & & & \\
\hline & Зацікавленність & & & & & & & & \\
\hline \multirow{3}{*}{$\begin{array}{l}\text { Негативні } \\
\text { реакції }\end{array}$} & Відсутність цікавості & & & & & & & & \\
\hline & Балачки & & & & & & & & \\
\hline & Шум & & & & & & & & \\
\hline \multicolumn{2}{|c|}{ Хронометраж уроку } & $5 \times 8$. & 10 хв. & $15 \mathrm{xB}$. & $20 \mathrm{xB}$. & $25 \mathrm{xв.}$ & 30 хв. & 35 хв. & $40 \mathrm{xB}$. \\
\hline
\end{tabular}


Таблиця 3 - Технологія мікродраматургії у презентації творів мистецтва

\begin{tabular}{l|l}
\hline $\begin{array}{c}\text { Етап алгоритму } \\
\text { мікродраматургії }\end{array}$ & \multicolumn{1}{|c}{ Художньо-педагогічний зміст етапу } \\
\hline Зав'язка & $\begin{array}{l}\text { організація процесу художнього сприйняття: введення в емоційну атмосферу твору, по- } \\
\text { становка проблеми }\end{array}$ \\
\hline Експозиція & сюжет твору, історія створення, аналіз засобів художньої виразності, стилістичні ознаки \\
\hline Кульмінація & розв'язання моральної проблеми твору, розкриття змісту художнього образу \\
\hline Розв'язка & художня рефлексія, моральний висновок \\
\hline
\end{tabular}

Головними змістовими та структурними складовими уроку інтегрованого курсу «Мистецтво» виступають художні твори, розташування їх у структурі заняття, поєднання та комбінація різних прикладів повинно відповідати художній та дидактичній меті освітнього процесу. Звернення до прийомів драматургії при безпосередній презентації твору на уроці може бути реалізованим у вигляді технології мікродраматургії. Отже, презентація творів мистецтва розгортається за логікою розвитку дії в контексті пізнання учнями змісту художнього образу та аналізу засобів виразності. Твори мистецтва різних видів мають власну специфіку, пов'язану із особливостями художньої мови кожного $з$ мистецтв, але молодому вчителю можна порекомендувати технологію мікродраматургії як своєрідний алгоритм аналізу за допомогою якого можливо універсалізувати процес презентації змісту твору мистецтва на уроці.

Отже, в даній статті ми спробували охарактеризувати явище художньої драматургії в контексті використання його як засобу художньої дидактики в наступних аспектах:

- як засіб організації цілісного освітнього простору уроку інтегрованого курсу «Мистецтво»;

- як засіб регламентації дій учасників освітнього процесу: Учителя, як транслятора художньо-педагогічної інформації, своєрідного «творця» уроку мистецтва, сценариста, режисера, актора, та Учнів, як реципієнтів художньої педагогічної інформації, глядачів та учасників художньо-педагогічного дійства;

- як технологію презентації головної інформаційної складової - твору мистецтва на уроці- «мікродраматургію».

Оприлюднені рекомендації, таблиці та схеми спираються на багаторічний досвід автора у викладання дисципліни «Художня культура» та результати педагогічної практики 3 інтегрованого курсу «Мистецтво» студентів кафедри музичного мистецтва Миколаївського національного університету імені В. О. Сухомлинського.

Нові виклики української освіти вимагають переосмислення підходів до організації освітнього середовища. «Школа пам'яті» змінює орієнтацію на «школу розвитку», де вимоги до шляхів отримання знань, прямують через різноманітні інформаційні джерела, у тому числі і через мистецтво. В умовах Нової української школи трансформується і мистецька галузь, набуваючи великого значення для розвитку необхідних для сучасного учня компетенцій та вмінь: загальнокультурної компетенції, емоційного інтелекту, критичного мислення тощо. У свою чергу новий зміст мистецької галузі потребує оновлення та переосмислення оперативного інструментарію - методів, прийомів та технологій. Одним з засобів художньої дидактики є явище художньої драматургії, яке екстраполювалося на педагогічну практику як принцип організації освітнього простору на різних рівнях: структури заняття, організації процесів художнього сприйняття та змісту художньо-інформаційних блоків. Для адекватного втілення прийомів художньої драматургії майбутньому вчителю потрібно опанувати спеціальні вміння: мовну та акторську майстерність, володіння музичним інструментом, елементарними хореографічними та образотворчими навичками, адже вчитель - виконавець дійства уроку, сценарист та режисер художньої драматургії. Перший приклад творчості надається дітям самим вчителем, коли при знайомстві з творами мистецтва інтерпретує музичні чи живописні образи, пов'язуючи їх емоційну тональність із своїм світовідчуттям. «Лише там, де урок - мистецтво, є місце і самому мистецтву» (Є. Іл'їн). Головною метою зусиль вчителя мистецтва, озброєного методом художньо- педагогічної драматургї $є$ - викликати емоційний відгук своєю майстерністю, надати дитині приклад як реалізувати себе як творчу особистість.

\section{Список використаних джерел}

1. Богданова I. М. Технології в освіті : теоретико-методологічний аспект : монографія / І. М. Богданова. - Одеса : ТЕС, 1999. - 146 с.

2. Масол Л. Методика навчання мистецтва у початковій школі: посібник для вчителів. -Х.Веста:Вид-во «Ранок», 2006. С. 60-62.

3. Масол Л. М. Загальна мистецька освіта : теорія і практика : монографія / Л. М. Масол. - К. : Промінь, 2006. - 432 с. 
4. Падалка Г. М. Педагогіка мистецтва. Теорія і методика викладання мистецьких дисциплін / Г. М. Падалка. - К. : Освіта України, 2008. - 274 с.

5. Рудницька 0. П. Педагогіка: загальна та мистецька : навчальний посібник / О. П. Рудницька. - Тернопіль : Навчальна книга-Богдан, 2005. - 360 с.

6. Щолокова О. П. Методика викладання світової художньої культури : підручник для студ. пед. ун-тів / О. П. Щолокова. - Вид. 2-е - К.: Видавництво НПУ ім. М. П. Драгоманова, 2009. - 288 с.

\section{References}

1. Bogdanova I. M. (1999) Texnologiyi v osviti : teorety'ko-metodologichny'j aspekt : monografiya. [Technologies in education: theoretical and methodological aspect: monograph]. Odesa : TES.

2. Masol L. (2009) Pidhotovka vchyteliv do polikhudozhn'oho vykhovannya uchniv. [Preparation of Teachers for Polyart Education of Pupils]. Kyiv:Mystetstvo i osvita. № 2, 4-7.

3. Masol L. (2006) Zahal'na mystets'ka osvita : teoriya i praktyka : monohrafiya. [General artistic education: theory and practice: monograph]. Kyiv:Promin.

4. Padalka H. M. (2008) Pedahohika mystetstva. Teoriya i metodyka vykladannya mystets'kykh dystsyplin. [Pedagogy of Art. Theory and methodology of teaching artistic disciplines]. Kyiv:Osvita Ukrayiny.

5. Rudnyts'ka O. P. (2005) Pedahohika: zahal'na ta mystets'ka : navchal'nyy posibnyk. [Pedagogics: general and artistic: a tutorial texbook]. Ternopil' : Navchal'na knyha-Bohdan.

6. Shcholokova O. P. (2009) Metodyka vykladannya svitovoyi khudozhn'oyi kul'tury : pidruchnyk dlya stud. ped. un-tiv [The method of teaching the world's artistic culture: a textbook for the students of pedagogical universities]. Kyiv: Vyd-vo NPU im. M. P. Drahomanova.

Юлия Хайрулина. Приёмы художественной драматургии в подготовке учителя музыкального искусства к преподаванию интегрированного курса «Искусство» в условиях Новой украинской школы

В статье проанализированы методические основы подготовки учителя музыкального искусства к преподаванию интегрированного курса «Искусство» в условиях Новой украинской школы. Актуализировано явление художественной драматургии в контексте использования её закономерностей в контексте педагогики искусства. Рассмотрены особенности использования приемов художественной драматурги при упорядочении структурно-содержательных элементов современного урока искусства в общеобразовательном учереждении. Даны рекомендации касательно использования художественной драматурги как образовательной технологи. Описано уровни использования художественной драматурги на уроке. Приведено схему урока искусства, где объединены общедидактические требования и элементы художественной драматургии. Рекомендована методика наблюдения и фиксации емоциональной реакции учеников на ход урока искусства с целью прогнозирования успешности учебной деятельности и усовершенствования методической подготовки будущих учителей искусства.

Ключевые слова: Новая украинская школа, учитель музыкального искусства, художественная драматургия, интегрированный курс «Искусство», урок искусства, образовательная технология, эмоциональная партитура урока.

Yulia Khairullina. The techniques of artistic drama in the preparation of a teacher of musical art to the teaching of the integrated course «Fine Art» in the context of the New Ukrainian School

The article analyzes the methodological foundations of the preparation of a musical art teacher for teaching the integrated course "Art» in the conditions of the New Ukrainian school. It actualized the phenomenon of artistic dramaturgy in the context of application its regularities in the pedagogy of art. It was considered the features of using the techniques of artistic dramaturgy for ordering the structural and content elements of the modern «art lesson» in the secondary school. It was provided some recommendations to applicate the artistic dramaturgy as an educational technology. The levels of using the artistic dramaturgy at the lesson was describe. Dramaturgy, as «the art of constructing a dramatic work» is described by Aristotle, at that time, the main feature is formulated as the presence of action, changes in events in time. Using of artistic dramaturgy in pedagogy dates back to the 1960's and 70's of the twentieth century, when the implementation of new programs for a secondary school required updated methodological approaches. Ukrainian researchers of the problem of an artistic dramaturgy in the field of pedagogy ( O. Rudnitskaya, O. Sholokova, G. Padalka, L. Masol) provided the definition of the concept and levels of its existence in the art of pedagogy. According to previous studies, and based on his own intelligence, the author of the article gives the diagram of the art lesson, where was connected the didactic requirements to school lesson with the elements of the artistic dramaturgy. The author recommends a methodology of tracking the pupil's emotional reactions for the forecasting the successful educational activity and improving the methodological training of future art teachers. In order to adequately implement the techniques of fiction dramatics, the future teacher needs to master special skills: linguistic and acting skills, possession of a musical instrument, elementary choreographic and pictorial skills, because the teacher is the performer of the lesson, screenwriter and director of artistic dramaturgy.

Key words: New Ukrainian School, musical art teacher, artistic dramaturgy, integrated course «Fine Arts», educational technology, emotional score of lesson. 